\title{
LEITURA: MEDIAÇÃO E MEDIADOR
}

BARROS, Maria Helena T. C. de; BORTOLIN, Sueli; SILVA, Rovilson José da. Leitura: mediação e mediador. São Paulo: FA, 2006. 160 p.

Entre você e eu, entre o mundo e nós, a palavra. Ela permeia nosso estar no mundo e ao mesmo tempo nos liga a ele e a nós mesmos. A palavra, que chega para ficar, ou aquela que mal dá tempo de olhar. No mundo das letras, dos caracteres, das palavras, frases, sentidos, silêncios, expressões e omissões, há o nosso aproximar-se ou a manutenção da distância. Por vezes - quase sempre, parece - para achegar-se a esse universo há que se ter mediação; carecemos da presença do outro.

Autores das áreas de Ciência da Informação e Letras, que de longa data têm focalizado a leitura como paixão e profissão juntaram-se, misturando seus artigos, teses e vivências em escolas, para tratar da leitura, do jovem leitor e dos mediadores, que atuam ou poderiam atuar junto a ele em casa, na escola e na biblioteca. Nesse universo eles destacam as implica- ções da relação do leitor (potencial e real), mediador e livro.

A obra é prefaciada por Dagoberto Buim Arena, que tece considerações acerca do desenvolvimento da leitura no Brasil. Ele aponta os envolvidos nesse processo e os espaços de leitura na escola, chamando a atenção para contradições das políticas públicas nos espaços institucionais. Menciona a diferença de pronunciar palavras e o saber ler e, nesse âmbito, a atenção que se deve à mediação do professor na sala de aula e na biblioteca.

A apresentação anuncia que a obra é resultante das preocupações e questionamentos feitos pelos autores, todos eles pesquisadores unidos pela mesma temática, em especial no que se refere aos jovens. Evidencia, capítulo por capítulo, as idéias tratadas e os tópicos focalizados.

O adolescente e temas que Ihe são pertinentes como as bibliotecas pública e 
escolar e a literatura; sexo, saúde e violência; os aparatos eletrônicos de leitura; os contos e as histórias na escola e, por último, as classes especiais, são colocados para o leitor, vistos sob a ótica da mediação familiar ou escolar.

Em "A mediação da leitura na biblioteca", Maria Helena T. C. Barros explicita conhecimentos necessários aos mediadores de leitura e a atenção que se deve dispensar no atendimento ao leitor autônomo ou àquele que ainda está em fase de aproximação dos livros. Da tese de doutoramento da autora em Ciência da Comunicação pela ECA/USP, nasceram "A biblioteca pública e a leitura do adolescente" e "O adolescente e a leitura da literatura". O último parte de uma pesquisa desenvolvida em bibliotecas públicas no estado de São Paulo, por meio da qual foram arrolados 282 títulos de obras variadas. Desses, são destacadas as dez primeiras posições e os comentários referentes a estas obras. A autora avalia, nesse quadro, a mediação reprodutora da escola, que continua presa às indicações do passado. No texto anterior, o adolescente é mostrado na sua condição de leitor ainda pouco compreendido como público alvo. Em outros quatro artigos: "Vó, me conta uma história?", "O bibliotecário e o ato de ler", "O professor como mediador de leitura" e "De leitura, classes especiais e bibliotecas escolares", Barros apresenta nuances diferenciadas da temática tratada, sem perder de vista a profun- didade das abordagens feitas. As experiências como docente na Universidade Estadual Paulista - UNESP/Marília - e pesquisadora do CNPq se fazem presente em suas argumentações.

Sueli Bortolin, a seu tempo, traz à tona os textos "A leitura literária em suportes eletrônicos na biblioteca infanto-juvenil" e "A mediação de leitura nos espaços infanto-juvenis", além de compartilhar com Silva, "Das prateleiras às mãos" e com Borges, "Hora da história: toda criança merece". Com base fortemente calcada no trabalho junto ao SESC (14 anos), à Livraria Maluquinha (4 anos), a ONG de leitura e na vivência recente à frente da Biblioteca Central de uma universidade pública (Universidade Estadual de Londrina - UEL), a autora analisa os conceitos de biblioteca infanto-juvenil e os avanços tecnológicos, destacando a leitura por meio eletrônico, sempre entremeando sua exposição de idéias com a questão da mediação da leitura.

Silvia Bortolin Borges, parceira intelectual de Sueli, é Pedagoga com Especialização em Didática. Atua na Educação Infantil, no Ensino Fundamental e Médio e é uma exímia contadora de histórias. Durante o período de 2000/2004 foi docente da Universidade Filadélfia em Londrina e atualmente faz parte da diretoria da Ong MUNDOQUELÊ, da qual também fazem parte Sueli e Rovilson. 
Rovilson José da Silva coordena o Projeto "Palavras Andantes" na Prefeitura Municipal de Londrina e nesse espaço tem mudado a concepção de biblioteca no âmbito escolar não só no momento em que está formando mediadores de leitura, mas também quando faz articulações para que esse gênero de biblioteca tenha seu acervo melhorado, seu mobiliário trocado e sua arquitetura (lay-out) alterada de forma a tornar esse local aprazível para se permanecer, voltar. Além do texto compartilhado com Bortolin, chama a atenção para implicações d'"A hora do conto na escola: paradoxos e desafios" e lembra que pouco se tem pesquisado acerca do professor como mediador de leitura. A partir de um estudo acerca do texto literário e sua utilização pelo professor da Hora do Conto, o autor analisa entrevistas com professores e apresenta suas conclusões a respeito. Diz das suas inquietações no tocante à relação biblioteca-escola, da maneira como conduziu as entrevistas com os professores e da sua proposta defendida junto à Rede Municipal de Ensino de Londrina.

O fio condutor dos textos nos faz lembrar que neste início do século XXI temos as atenções voltadas para a leitura como nunca visto anteriormente. Instituições governamentais, ONGs, mídia e parques editoriais têm se dedicado a esta temática. No entanto, o alardear nem sempre vem acompanhado de efetivo envolvimento em busca de alterar para melhor, a situa- ção atual. Neste quadro, o livro ora resenhado merece ser lido, por tratar com seriedade um tema tão próximo de todos nós, mas ainda tão pouco compreendido por aqueles que o têm como matéria-prima em seu trabalho. São escritos de leitores que se ocupam da formação de quem lê e dos espaços que the são próprios - as bibliotecas. Vale a pena conferir!

Lucinea A. Rezende

Professora do Departamento de Educação (UEL). Doutora em Educação lucinea@uel.br

\section{Title}

Reading: mediation and mediation agent

\section{Título}

Lectura, mediación y mediador 